Vol. 2, No. 1, Desember 2021

\title{
PELATIHAN PEMASARAN DIGITAL PADA UMKM BATIK DI WILAYAH PAKISAJI, KABUPATEN MALANG
}

\author{
Ricky Angga Ariska \\ Universitas Wijaya Kusuma Surabaya \\ rickyanggaariska@uwks.ac.id \\ Santirianingrum Soebandhi \\ Universitas Wijaya Kusuma Surabaya \\ santirianingrum@uwks.ac.id \\ Fadilla Purwitasari \\ Universitas Wijaya Kusuma Surabaya \\ fadilla_purwitasari@uwks.ac.id
}

Info Artikel

\section{Diterima:}

28-10-2021

Direvisi:

24-12-2021

Diterbitkan:

24-12-2021

\begin{abstract}
Abstrak
Pemasaran produk merupakan salah satu permasalahan klasik yang dihadapi oleh para pemilik usaha, terutama yang termasuk dalam UMKM. Salah satu strategi yang dapat dilakukan pada masa pandemi ini adalah dengan mengikuti perkembangan teknologi. Salah satu bentuk promosi yang mengikuti adaptasi teknologi adalah dengan menggunakan promosi digital. Bentuk promosi digital telah banyak dilakukan oleh para pelaku UMKM, namun banyak pengusaha yang belum mengetahui tentang aplikasi apa saja yang bisa digunakan untuk melakukan pemasaran secara online.

Kegiatan pengabdian masyarakat ini berupa sosialiasi mengenai strategi dan aplikasi apa saja yang dapat digunakan sebagai media pemasaran bagi pelaku UMKM Batik di wilayah Pakisaji, Kabupaten Malang. Pelatihan akan diberikan dalam dua langkah yang terdiri dari pemberian materi dan penjabaran contoh-contoh aplikasi yang dapat digunakan sebagai media pemasaran

Kata Kunci: pemasaran digital, UMKM Batik

Pakisaji, strategi pemasaran
\end{abstract}

DOI: $10.29303 / a b d i m a s s a n g k a b i r a . v 2 i 1.64$

\section{Pendahuluan}

Pakisaji adalah salah satu nama kecamatan di Kabupaten Malang. Kecamatan Pakisaji berbatasan langsung dengan Kota Malang di sebelah utara. Posisinya yang dekat dengan keramaian kota menjadikannya salah satu daerah wisata yang potensial bagi Kabupaten Malang. Kondisi ini kemudian dimanfaatkan oleh Pemerintah Kabupaten Malang dengan memfokuskan kelahiran salah satu ikon batik Kabupaten 
Malang di Desa Genengan, Kecamatan Pakisaji. Untuk membentuk ikon batik tersebut, yang kemudian diharapkan akan menopang kepariwisataan Kabupaten Malang, pemerintah daerah melakukan usaha yang maksimal dengan memberikan bantuan dalam pembinaan sumber daya manusia serta fasilitator yang dapat memberikan berbagai masukan. Salah satunya adalah dengan menggelar acara Peningkatan Kualitas Pengrajin Batik pada tahun 2017 di Tempat Wisata Bonderland Pakisaji. (Nana, 2017)

Usaha untuk menggairahkan industri batik di Kecamatan Pakisaji terus dilakukan. Namun, usaha ini belum membuahkan hasil yang diharapkan. Salah satu contoh usaha yang dilakukan adalah acara Gema Desa yang dilakukan pada tanggal 19 Maret 2019 untuk menyalakan kembali motivasi dan energi baik bagi warga Pakisaji untuk menjadikan wilayahnya sebagai kampung batik (Nana, 2019). Asa para pengrajin batik untuk mengembangkan usahanya tetap berkobar. Namun keinginan untuk membesarkan usaha ini tersendat dikarenakan masalah akses pasar dan permodalan. Keluhan ini disampaikan oleh Supriadi, Wakil Ketua Paguyuban Pengrajin Batik Kabupaten Malang, kepada salah satu kader partai yang melakukan kunjungan ke lokasi workshop Batik Pakisaji (Naiobe, 2020).

Pemerintah Daerah Kabupaten Malang terus mengucurkan tenaga untuk mengembangkan usaha batik di wilayah Pakisaji. Salah satu hal yang dilakukan adalah memberikan Pelatihan Batik Lanjutan yang dilakukan oleh Dinas Perindustrian dan Perdagangan Kabupaten Malang di Balai Desa Pakisaji pada tanggal 10 September 2020. Salah satu materi yang diberikan adalah materi tentang solusi dan strategi cara mengelola keuangan dengan baik bagi pelaku UMKM di masa pandemi. Salah satu strategi keuangan yang dapat dilakukan adalah dengan melakukan pemisahan antara pengelolaan keuangan untuk usaha dan pengelolaan keuangan untuk kepentingan keluarga. Selain itu, disampaikan pula bahwa pemasaran produk adalah salah satu permasalahan yang dihadapi pelaku UMKM selama masa pandemi Covid19. (NN, 2020)

Pemasaran produk merupakan salah satu permasalahan klasik yang dihadapi oleh para pemilik usaha, terutama yang termasuk dalam UMKM. Salah satu strategi yang dapat dilakukan pada masa sekarang ini adalah dengan mengikuti perkembangan teknologi. Salah satu bentuk promosi yang menngikuti adaptasi teknologi adalah dengan menggunakan promosi digital. Bentuk promosi digital telah banyak dilakukan oleh para pelaku UMKM, namun banyak pengusaha yang belum mengetahui mengenai aplikasi-aplikasi yang dapat mendukung kegiatan pemasaran digital usaha mereka.

Berdasarkan pemaparan di atas, dapat ditunjukkan kebutuhan para pengusaha UMKM batik mengenai strategi-strategi dan aplikasi-aplikasi apa saja yang dapat digunakan oleh sebagai media promosi digital mereka. Oleh karena itu, tema pengabdian masyarakat yang akan dilakukan adalah pelatihan mengenai strategistrategi dan aplikasi-aplikasi yang dapat digunakan sebagai media pemasaran digital bagi pelaku UMKM Batik di wilayah Pakisaji, Kabupaten Malang 


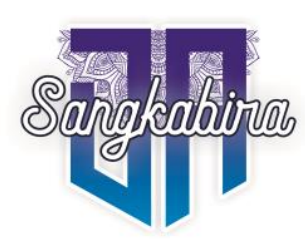

Vol. 2, No. 1, Desember 2021

\section{Metode}

Kegiatan pengabdian masyarakat ini akan dilaksanakan dalam bentuk pelatihan mengenai strategi-strategi dan aplikasi-aplikasi yang dapat digunakan sebagai media pemasaran digital bagi pelaku UMKM Batik di wilayah Pakisaji, Kabupaten Malang. Pelatihan ini akan dilaksanakan dalam 3 langkah, yaitu pemberian materi, penjabaran contoh, dan praktek. Berikut akan dijabarkan mengenai detail setiap langkah pelatihan yang akan dilaksanakan.

1. Pemberian Materi

2. Pemberian materi akan dilakukan di awal pelatihan. Materi yang diberikan berupa penjelasan tentang definisi pemasaran digital, alasan mengapa penggunaan pemasaran digital lebih menguntungkan di masa sekarang, dan proses inti pemasaran digital.

3. Penjabaran Contoh

Penjabaran contoh dilakukan setelah materi diberikan. Penjabaran contoh ini berupa menampilkan strategi-strategi dan aplikasi-aplikasi apa saja yang dapat digunakan untuk memasarkan produk batik secara digital. Beberapa strategi pemasaran digital yang dapat digunakan adalah menggunakan jasa influencer, pemakaian website, atau pemakaian search engine optimization. Sedangkan aplikasi-aplikasi yang dapat digunakkan sebagai sarana pemasaran digital bagi pengusaha batik adalah Google My Business, Whatsapp Business, atau email bisnis.

4. Praktek

Langkah terakhir dari sosialisasi ini adalah praktek penggunaan aplikasi yang dapat digunakan sebagai media pemasaran digital bagi pengusaha UMKM batik. Tidak semua aplikasi pemasaran digital diajarkan penggunaannya dalam sesi praktek ini. Hanya aplikasi Google My Business yang diajarkan dalam sesi ini. Hal ini dikarenakan keterbatasan waktu.

\section{Hasil}

Kegiatan pengabdian masyarakat ini dilakukan di pendopo kantor Kecamatan Pakisaji, Kabupaten Malang, Provinsi Jawa Timur. Hal ini karena acara ini merupakan bentuk kerjasama antara Camat Pakisaji dan tim pengabdian masyarakat untuk meningkatkan pengetahuan para pengusaha batik di daerah Pakisaji mengenai strategi pemasaran digital dan aplikasi-aplikasi yang dapat digunakan sebagai media pemasaran digital.

Hasil sosiasialisasi dan tanya jawab kepada para peserta menunjukkan bahwa pengetahuan para pengusaha UMKM batik di daerah Pakisaji mengenai strategi pemasaran digital masih rendah. Hal ini diketahui dari sikap peserta yang antusias saat pemateri menyajikan berbagai strategi pemasaran digital yang sedang trend dan berbagai pertanyaan yang diajukan mengenai penggunaan aplikasi pemasaran digital yang sedang popular. 


\section{Diskusi}

Kegiatan pengabdian masyarakat ini dimaksudkan untuk menambah pengetahuan para pengusaha UMKM mengenai strategi dan aplikasi pemasaran digital yang sedang trend. Dari hasil dari sosialisasi dan sesi tanya jawab yang menyertainya dapat diketahui bahwa pengetahuan para pengusaha UMKM batik di daerah Pakisaji masih rendah dan sikap antusias dari para peserta untuk meningkatkan pengetahuan tersebut. Hal ini menunjukkan bahwa sosialisasi mengenai strategi pemasaran, terutama strategi pemasaran digital yang sedang popular, sangat dibutuhkan oleh para pengusaha UMKM. Berbagai pengetahuan tentang strategi dan aplikasi pemasaran digital ini, menurut para pengusaha UMKM tersebut, dapat digunakan untuk memperluas cakupan pemasaran mereka, yang pada akhirnya diharapkan dapat membantu meningkatkan penjualan mereka.

\section{Kesimpulan}

Berdasarkan kegiatan pengabdian yang dilakukan terlihat bahwa para pengusaha batik dari daerah Pakisaji banyak yang belum mengetahui mengenai strategi dan aplikasi pemasaran digital yang dapat diterapkan untuk usaha batiknya. Dengan adanya sosialisasi ini, diharapkan dapat menambah pengetahuan para pengusaha batik di daerah Pakisaji mengenai strategi dan aplikasi yang dapat digunakan untuk pemasaran digital.

\section{Pengakuan/Acknowledgements}

Terima kasih kami sampaikan kepada pihak-pihak yang turut terlibat langsung dalam mesukseskan kegiatan pengabdian kepada masyarakat ini yakni: Bapak Mumuk Hadi Martono, SH., M.Hum. selaku Camat Pakisaji dan pihak Fakultas Ekonomi dan Bisnis Universitas Wijaya Kusuma Surabaya selaku penyandang dana kegiatan pengabdian masyarakat ini.

\section{Daftar Referensi}

Naiobe, Y. Paguyuban Batik Kabupaten Malang Keluhkan Akses Pasar dan Permodalan. $\quad$ https://kilas24.com/paguyuban-batik-kabupaten-malangkeluhkan-akses-pasar-dan-permodalan/, (January 27, 2020).

Nana. Disparbud Kabupaten Malang Support Lahirnya Ikon Batik. https://www.malangtimes.com/baca/17999/20170413/160152/disparbudkabupaten-malang-support-lahirnya-ikon-batik, (April 13, 2017).

No Name (N.N). Dr. Tantri Motivasi Pengrajin Batik Kabupaten; Tetap Produksi Dimasa Pandemi. http://www.jurnalmalang.com/2020/09/dr-tantri-motivasi-pengrajinbatik.html?m=1, 2020.

Nana, D. Pantang Surut, Jajuk Rendra Kresna Siap Kawal Kampung Batik Pakisaji Terwujud, asal... https://malangtimes.com/baca/37170/20190319/162300/pantang-surut-jajukrendra-kresna-siap-kawal-kampung-batik-pakisaji-terwujud-asal, (March 19, 2019). 